\title{
THE HUNTER'S ROLE IN MOOSE MANAGEMENT
}

DOUG ELSASSER, Saskatchewan Tourism and Renewable Resources, 3211 Albert Street, Regina, Saskatchewan. S4S 5W6

When the new Moose Management Program was introduced in 1977, a number of people were sceptical. "Don't Shoot Her! You're Breaking the Law" was the blunt message sportsmen received. A selective harvest of calf or bull Moose was something new for Saskatchewan hunters. Access to moost hunting had for several years been limited by draw seasons. Moose herds were still faultering after the deadly 1973-74 winter.

The new program was introduced only after wildlife managers in Saskatchewan had reviewed moose management programs throughout the Northern Hemisphere; and settled on the promising Swedish strategy: Protect prime breeding stock - expand populations and hunting opportunity at the same time. The program's success depended on support by resident hunters. Game identification was stressed more than ever before.

It appears that the effort was worthwhile. Indications are that the new Moose Management Program is working. Hunters can take credit for this. They responded to the challenge and proved that responsible moose management was indeed "their game."

Protecting cow Moose during the regular seasons is the backbone of this new management strategy. Evidence collected at check stations by the provincial Wildlife Branch shows that the average age of cow Moose in the wild has increased since 1977. More female animals are now alive and well in the productive 5 to 10 year-old class.
Prime-aged cows have healthier twins and are better able to care for them. As the crop of moose calves increases each year, so will the population continue to expand to fill available habitat.

Hunter success in the 1980 regular season was 39 percent. This is the highest success rate recorded since the program began. On the average, it took hunters 11.3 days to bag a calf or bull Moose. This is much lower than the 17.8 days per animal bagged figure of 1979 , and suggests that more moose are available to sport hunters.

In terms of outdoor recreation supplied, the 1980 regular season was equal to 1979 with 44,000 hunter-days recorded. ("Hunter-days" are a measure of time spent afield in pursuit of game. If you hunted seven days for Moose last year, your hunting effort for that species was seven "hunter-days"). Some 11,000 persons purchased regular season moose licences last fall. Another 3,000 obtained a special moose licence. This is a vast improvement from the "draw days" when only a percentage of moose hunters were allowed a licence. Now, everyone who cares to hunt calf or bull Moose in any open zone has only to buy a licence.

A statistic of concern to Wildlife Branch biologists is the small harvest of calf Moose in 1980. From a three-year average of 27 percent, the calf harvest fell to 19 percent last fall. This put increased pressure on bull Moose. In light of these figures, a number of suggestions were made to the Game 
Advisory Committee to increase the harvest of young animals. Permitting the harvest of two calves or one bull per hunter was considered. So was a "calf only" season. Finally it was decided to appeal directly to moose hunters, "Select more calves in the regular seasons." Accurate returns of the 1981 Hunter Questionnaire will tell wildlife managers if more calves have been harvested this fall.

Killing a calf Moose may not appeal to ardent trophy hunters or people who have been influenced by the "Bambi Syndrome"; but it is sound wildlife management in northern climates to harvest young-of-the-year animals. Calves suffer a high death rate their first winter if conditions are severe. They are more affected by deep snow and cold temperatures than adult animals. Calves, because they are growing so fast, don't always have time to store sufficient energy reserves (fat) which they need to withstand an extended period of cold and deep snow. In Saskatchewan and other "four-season" climates, big game animals have two distinct energy cycles: positive and negative. In winter, animals are into the negative cycle because they cannot consume enough food to cover their energy expenditures. Calories burnt to maintain body heat and wade through deep snow are drains on energy reserves. In the negative cycle (which lasts until "green-up" in the spring), animals rely on fat reserves stored in their bone marrow, under the hide, and around internal organs to supplement a low-protein winter diet. Calf Moose, especially if they are born late, frequently cannot store enough fat to last them through a prolonged winter. Consequently they starve or fall easy prey to predators. Harvesting them in the autumn takes pressure off prime breeding stock and has little effect on the survival of each year's calf crop. This is why it is sound management to select calf moose.

Since 1977, hunters have shot more calf and yearling Moose than adults in each regular season (Figure 1 ). This is a positive step towards stabilizing Moose

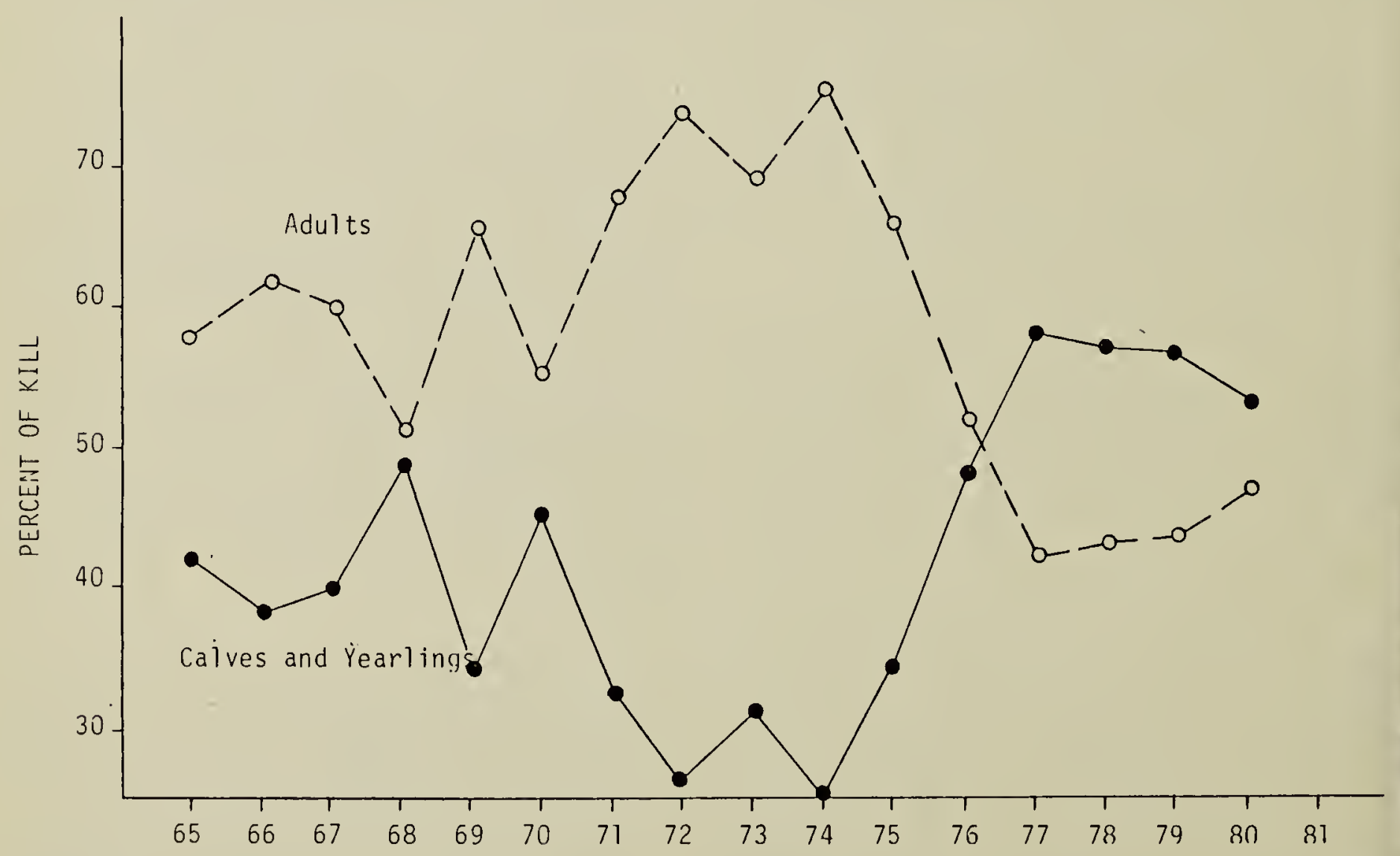

Figure 1. Age structure of Moose harvested in Saskatchewan, 1965 - 1980, as determined from checking station samples. 
populations. Again, in order to improve the new Moose Management Program, hunters are asked to select more calf moose.

Some hunters have asked themselves, "Are bull Moose being overharvested?"

To keep track of this serious possibility, the Wildlife Branch sponsors check stations and hunter questionnaires to gather information about the moose harvest. We also fly 10,000 kilometres $(6,000$ miles) of moose survey transects to collect population data. If too many bulls were being taken it would show up in two important areas. First, the average age of bulls in the harvest would decline; and secondly, the fertility rate of cows would drop in response to inadequate breeding stock. Neither of these is the case.

The average age of bulls taken through checking stations averaged 3.88 years in 1980 compared with 3.46 years in 1977. A veterinarian was hired during the 1980-81 winter to conduct pregnancy tests on cow Moose in management zone 27 . He found that 94 percent of cows tested were bearing calves, 25 percent carried twins. These indicators suggest that bull Moose are not presently being over-harvested, but the possibility will have to be guarded against.

The Moose herd in Saskatchewan has increased substantially since 1977 . Densities now exceed one Moose per square mile in most habitat types south of the Precambrian Shield. Where low populations are in evidence, no special season is held. Zones 28, 29 and 31 have warranted no special season for several years. Despite factors not found in Sweden like the year-round hunting

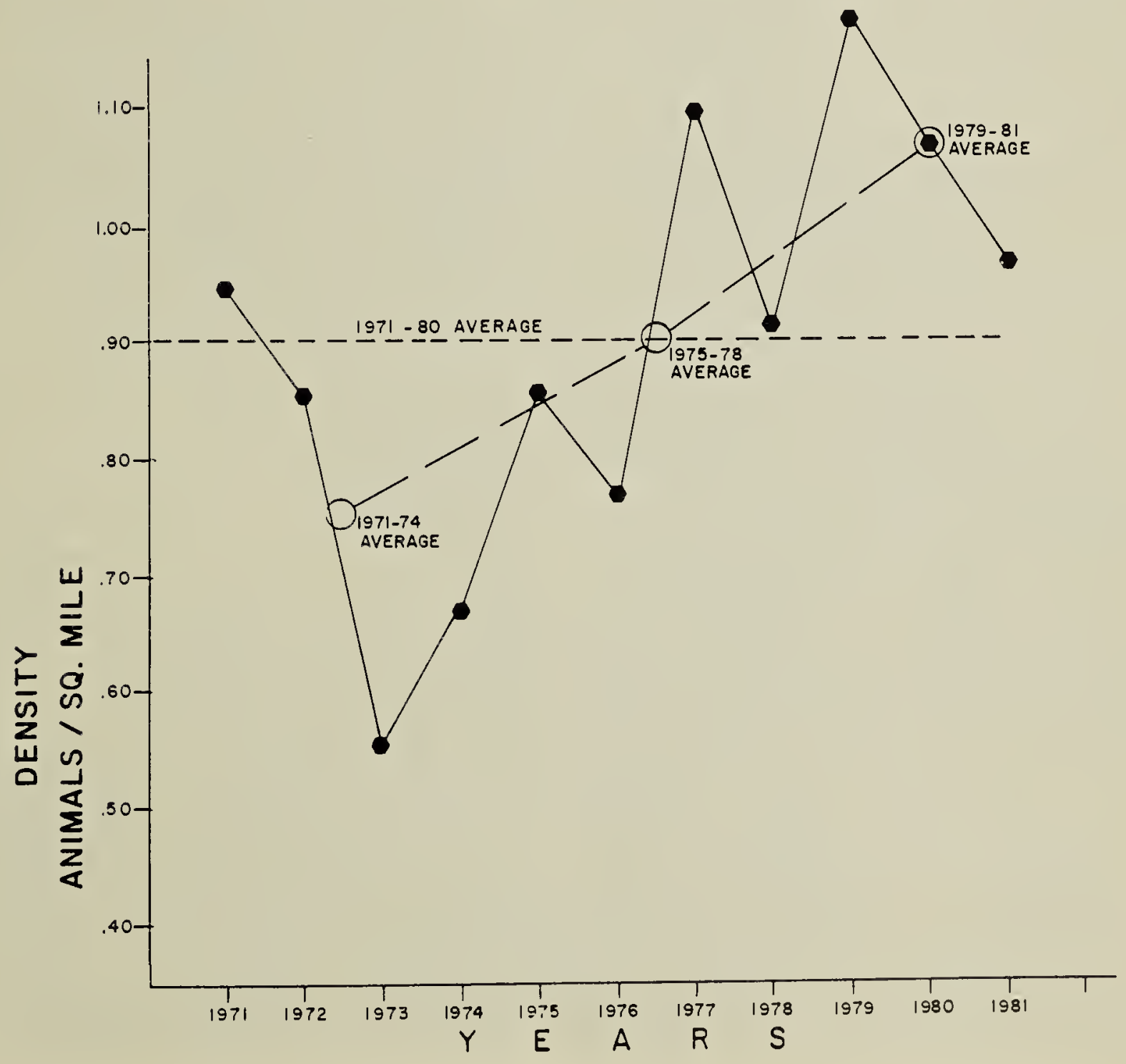

Figure 2. Provincial Moose population density 
rights of Treaty Indians, predators like wolves and bear, and more severe winters, the new Moose Management Program has proven that Saskatchewan herds can expand and hunting recreation can increase both at the same time (Figure 2).

As long as hunters co-operate meaning that they protect cow Moose during the regular season, select more calves, and provide the Wildlife Branch with feedback on hunting activities so we can keep track of the resource, there is no reason (barring a disastrous winter) why Moose herds should not continue to expand. Moose hunters are responsible for the continued success of the Moose Management Program. They are the true wildlife managers because their actions affect moose poulations directly. If you are in the forest this coming fall searching for Moose, and you see one, please be sure before you shoot!

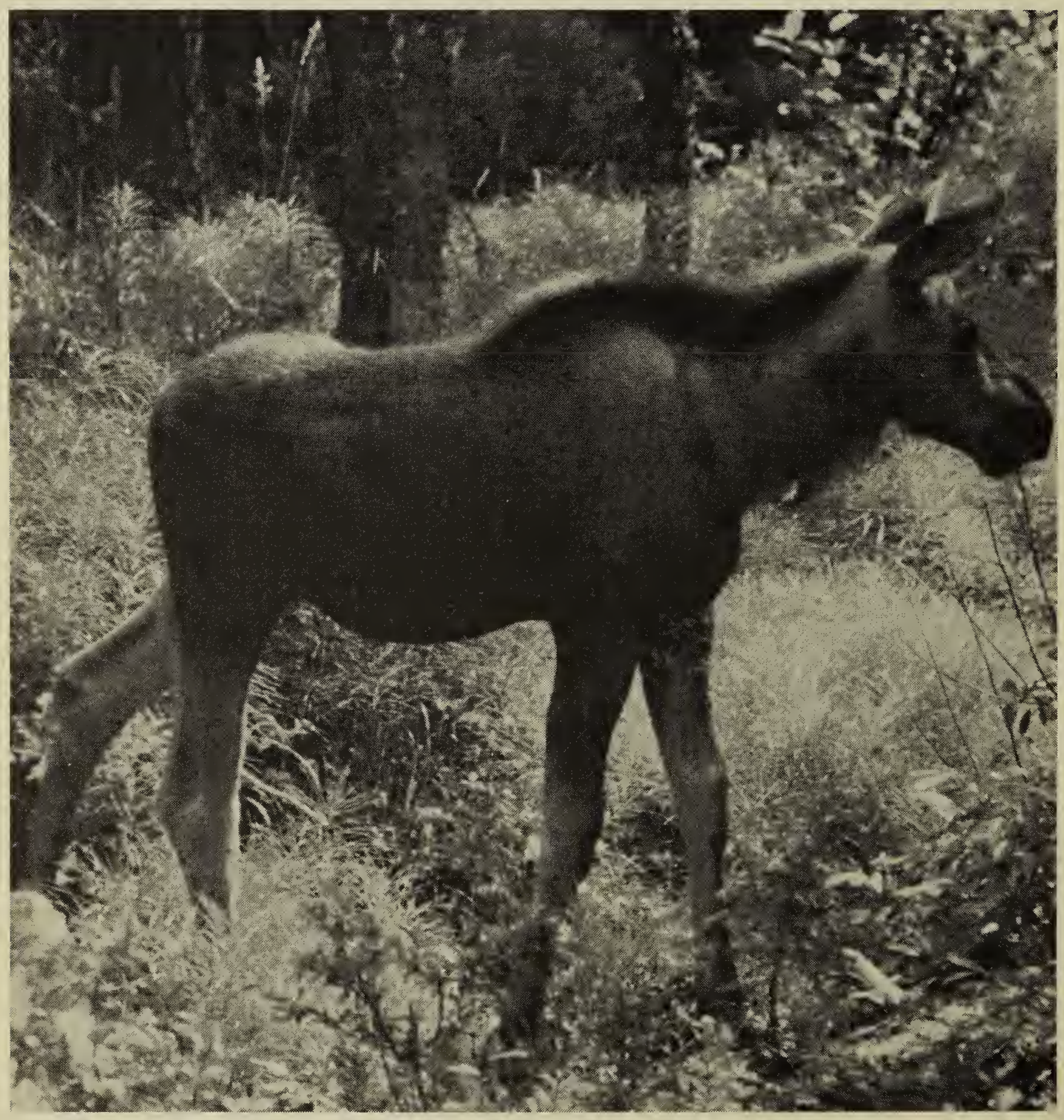

